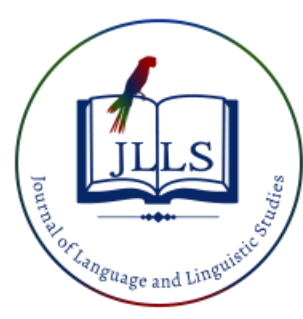

\title{
Stylistics as a tool for critical language awareness
}

\section{APA Citation:}

\author{
Lindita Tahiri $^{\text {a } 1 \text { iD, Nuran Muhaxheri }}{ }^{\text {b }}$ iD \\ ${ }^{a, b}$ University of Prishtina "Hasan Prishtina",Albania
}

Tahiri, L., \& Muhaxheri, N. (2020). Stylistics as a tool for critical language awareness. Journal of Language and Linguistic Studies, 16(4), 1735-1746.

Submission Date:30/05/2020

Acceptance Date:30/06/2020

\begin{abstract}
This study discusses the role of stylistic analysis in the development of critical language awareness (CLA) which is crucial for assessing ideologies transmitted in discourse. The Critical Stylistic approach is used to compare narrative strategies in fiction and non-fiction: in Ishiguro's novel The Buried Giant (2015) and in Wolff's book Fire and Fury: Inside the Trump White House (2018) by using analytical tools such as transitivity, participants, actions and processes, vocabulary, syntax, modality, generics, personal pronouns, speech acts. Considering ambiguous approaches to the issue of truth in mass media when hundreds of fact-checking sites are telling people how to separate 'true meaning' from 'fake meaning', this study argues that the linguistic approach to narratives can foster critical thinking by helping readers understand the interpretative nature of the meaning of the text. In the light of contemporary literary strategies, literature is affirmed as mode of 'truth' in the sense of an increased self-knowledge and insight on the part of the reader who carries out interpretation as opening up to the text in relation to multiple meanings. The stylistic approach towards narrative strategies is pointed out as prevention of prescriptive and dogmatic readings and as encouragement for critical literacy.
\end{abstract}

(C) 2020 JLLS and the Authors - Published by JLLS.

Keywords: critical language awareness; Ishiguro; Wolff; deictic shifting; unreliable narrator; speech act.

\section{Introduction}

The concept of 'critical language study' was proposed by the renowned Critical Discourse Analysis (CDA) representative Norman Fairclough, $(2001,2003,2010)$ as a necessary tool in education to increase consciousness on ways of using language. For Fairclough this skill is of crucial importance in developing the 'critical language awareness' (CLA) of practices, meanings, values and identities that are taught and learnt and ideologies that are transmitted in discourse (2010, p. 531). CLA according to Fairclough is related with the general social problematic of language and power in contemporary society: "Not only is education itself a key domain of linguistically mediated power, it also mediates other key domains for learners" (2010, p. 529). He relates this skill of reflexive analysis of language with the production of the text which for him has an interpretative character both for the writer and for the reader, because "the producer of the text constructs the text as an interpretation of the world.... Formal features of the text are traces of that interpretation. The traces constitute clues for the text interpreter.... The text

\footnotetext{
${ }^{1}$ Corresponding author.

E-mail address: lindita.tahiri@uni-pr.edu
} 
interpretation is the interpretation of an interpretation" (Fairclough, 2001, p. 67) resonating Plato's idea about the inability of artistic representation to depict the real world.

In this light of the need to arouse critical thinking skills, the stylistic approach to texts acquires a particular importance as a sharpening of interpreting skills. In teaching of literature, the field of stylistics is a helpful and valuable tool as it does not only aim to interpret messages of the literary work, but brings out interpretation as an effect of textual features, such as lexicon and syntax, depicting their function towards producing the literariness of a text (Simpson, 2004). Furthermore, Simpson states that stylistics has pedagogical usefulness because it of its basic principles such as being rigorous, retrievable, and replicable and in this way, it enables students to avoid impressionism during literary interpretation and to use the literary text as an argument for this interpretation.

This stylistic and linguistic approach towards teaching literature is compatible with the development of literary criticism in the couple of last decades. In particular due to the influence of linguistic studies, literature scholars are not seeing literariness as a special trait of literature but rather a potential of all language which may be present in different kinds of discourse. Moreover, this potential for creativity in language has been associated in cognitive linguistics as linked to the basic cognitive processes in language usage, with further more stresses the importance of CLA in education.

The concept of CLA as an awareness about the ideology in discourse can be also related to the tendency of literary criticism to challenge the notion of a single predetermined meaning of the text. The scholar Ann Kempe (2001) considers that it is important to find ways of minimizing the role of the literature teacher as the source of authoritative knowledge. This teaching strategy engages readers in the pursuit of knowledge and in practicing critical reflection towards the literary text, preventing them to accept passively the interpretation of the dominant culture and stimulating them to produce readings of their own. This teaching style corresponds with developments in reader response criticism, with representatives such as Stanley Fish, Wolfgang Iser, Louise Rosenblatt, David Bleich and so on. This literary school moves away from both intention and text, focusing on the reader as producer.

However, as McIntyre (2011) argues, the stylistic approach towards literature often struggles to find a place in the curriculum as it occupies a middle ground between linguistics and literary criticism due to the tension between these two fields: linguists see it as subjective, whereas literary critics consider it formalist. Therefore, there is a need to improve the integration of linguistic criticism and stylistics in the curricula of teaching literature, in particular taking into consideration the recent approaches of language of literature in relation to other discourses in terms of intersection and similarities rather as opposed to each other. As Weber says (1996), this perspective integrates the linguistic and literary study and develops the awareness of literature as language, which is beneficial both to teaching of language and teaching of literature.

\subsection{Literature review}

Following Fairclough's concept of CLA, a similar concern about the influence of language in adopting ideologies and world-views by readers has been expressed by Leslie Jeffries (2010), who has developed Critical Stylistics (CS) tools by advancing the methodology of CDA in identifying ideological elements of texts. In her book about opposition in discourse Jeffries discusses the influence of 'constructed opposition' or 'unconventional opposites' on readers' perceptions: “ [a]lthough the extremes of Orwellian brain-washing may have been discredited in the post-1984 world, there is as I write a new paranoia breaking out about the processes by which young men and women throughout the world are persuaded that killing themselves and others in suicide bombings is the right and virtuous thing to do." (126) As the power of persuasion of these people is achieved by using language, Jeffries adds that "[s]omewhere in that language is the key to changes of world-view and, I would argue, the 
text world that is presented by such language and the deictic center that the hearer/reader is invited to take up must be key to understanding this process." (127) She makes the distinction between the effect of reading fiction, which according to her does not have a lasting effect on our world-view as readers: " $[\mathrm{t}]$ hough we immerse ourselves in the world of polite society in the late 18th century to read a Jane Austen novel, and in the world of aliens and space travel to watch Star Wars movies, we are likely to revert to our own world-view pretty soon after the end of the experience, though a truly involving novel or film may sometimes leave us with the after-effects of having inhabited a different world for a few minutes or hours."(128) She considers that the deictic shifting back from the deictic center of the fiction to our own, is not as important and powerful as in the case of non-fiction. Her main argument is the frequent repetition of constructed opposites through the media, as for example the exposure to discourse which presents Russia or Islam as the opposite of all that is good, and "if in entering that world for a few minutes on the train each morning we assimilate that text world as our own, as we are bound to do to be a successful reader of the texts, then it is a matter of conjecture, or as I hope in future, testing, that this world-view may become our own." (129) Another argument is the closeness of the media world to the actual world we inhabit; however, in our opinion both these arguments could be valid for the language of fiction as well. Let us take the example of popular songs for instance, which the audience is constantly exposed to, and which are close to the daily world, or the example of popular literature and popular culture in general, which surround the audience and may create a habitual relation with the text by what Jeffries calls the assimilation of the text world as our own.

Discussing the similar concept of critical literacy, the scholar Pam Green (2001) says that there is a duality about literacy, and in the context of the school literacy can limit students instead of liberating them. Green considers that traditional literacy practices often reduce literacy to portray only the mainstream view of the world, and for him this kind of literacy is exploitative. He calls instead for means of developing critical literacy and for a system of education that would arouse skills and competences associated with critical thinking.

Ishiguro, whose novel is chosen as an example for analysis, is regarding by literary critics as a typical example of narratorial unreliability. The rhetorical device of unreliability, since Booth coined it in 1961 has undergone a lot of discussion, and as Sternberg and Yacobi (2015) say, it has suffered from many circular definitions. There have been various attempts to classify unreliability, such as Greta Olson's (2003) differentiation between 'fallible' and 'untrustworthy' unreliable narration, William Riggan's (1981) distinction between 'Pícaros', 'Madmen', 'Naïfs', and 'Clowns', Rimmon-Kenan's identification of three main sources of unreliability, in the narrator's limited knowledge, personal involvement, or value scheme, Dorrit Cohn's distinction between 'factual' and 'ideological' unreliability (2000), or Phelan's (2005) claim that unreliability is based on the role of the narrator, hence it can be unreliable reporting, unreliable interpreting, or unreliable evaluating. However, none of the definitions managed to bypass the issue of authorial agency and the problematic notion of the 'implied author', which appears both as the source and as the construction of the text. As Nünning claims "The trouble with all of the definitions that are based on the implied author is that they try to define unreliability by relating it to a concept that is itself ill-defined and paradoxical" (1997, p. 86).

In accordance with the aim of this paper, unreliable narration is considered as a mode of expression compatible with the post-modern spirit of thinking, or as Ansgar Nünning points out, "The almost steady rise of the unreliable narrator since the end of the eighteenth century suggests that there is indeed a close connection between the development of this narrative technique and the changing notions of subjectivity" (1997, p. 95). Fiction writers did not invent this device - they were simply reflecting the emerging cultural discourse whereby moral and epistemological questions were growing increasingly ambiguous. These new narrators were "modern" in the sense that they resembled a great many of us. 
Narratorial unreliability is very divergent from classic narrative, which as Todorov (1966) claims, most often uses the formula of the narrator standing behind the characters, who do not have any secrets from him. Obviously, this form exists in different degrees. The superiority of the narrator can be clear, let us say, in a knowledge of someone's secret desires (that the person himself does not know), or in the simultaneous knowledge of the thoughts of several characters (of which none of them is capable), or simply in the all-knowing narration of event. According to Todorov, the point of view from the perspective of the character is widely prevalent in literature, above all in the modern era. In this case, the narrator knows as much as the characters, he cannot supply an explication of events before the characters have discovered it. Todorov mentions the differences between the narration in the first person and in the third person, but always according to the point of view the same character has of events: the result, obviously, is not the same. He mentions the case of Kafka who began The Castle in the first person, and he modified this point of view only much later, changing to the third person but always in the aspect of the character who is equal to the narrator.

The intrusive narratorial stance towards characters has been compared to the scheme of the disciplined society envisaged by Foucault, where people are observed by a powerful guard that remains invisible himself, in particular when stories are told by an intrusive narrator who does not hide the judgmental and moralizing tone. These novels apt to spread clear and conclusive values, beliefs which are articulated with authority and with obvious didactic aim. On the contrary, novels of multiple perspectives are associated with a liberal stance that allows for multiple and ambiguous meaning. However, Cohn (1999, p. 177) says that she is skeptical for this correspondence, because the judgmental narrator is not necessarily understood as spokesman for the author but as a fictional voice, whose comments may not be reliable. There is not a mode and meaning correspondence, because the figural focalization may transmit decisive values, and an eloquent narrator may transmit ambiguities.

The literary critic Jesse Matz (2004) states that one of the important new developments of the modern novel is the replacement of a belief in absolute, knowable truth with a sense of relative, provisional truths, with the awareness of 'reality' as a constructed fiction. Modern writers do not aim to give a full or neutral version of a story, but they emphasize the limited perspective of the personal point of view. This scholar states that "perhaps the main talent of the modern novel... is its power to question the margins and contents of the self", and hence modern fiction 'has helped us to determine the very nature of selfhood' (2004, p. 181). What Matz calls 'the main talent of the modern novel', may be crucial for the contemporary reader, who lives within the uncertainty of the modern age, where everything is opened to redefinition, even to 'fakeness'. Within the today's doctrine of relativity, the subjective position has been gripped by the immense number of mass massages, which foreground the multiple choice of the 'right self', changing endlessly within the vast space of virtual technology.

\subsection{Research questions}

Taking into account that critical thinking today is commonly listed amongst the main skills belonging to generic competencies and to transferable, multifunctional knowledge, skills and attitudes that people could learn and develop in different ways and learning environments, this paper will focus on the effect of stylistic analysis on the development of this skill. Furthermore, considering the distinction that Jeffries makes between the effect of reading fiction, which according to her does not have a lasting effect on our world-view as readers as compared to non-fiction, this study aims to apply the similar analysis to both kind of texts, in order to answer the following research questions:

1. Why is stylistic analysis important to promote critical language awareness in education?

2. How does the effect of deictic shifting and the change of world-view differ in fiction and nonfiction? 


\section{Method}

In order to answer the research questions, the paper will compare fragments from both texts, using Critical Stylistics tools and applying Jeffries's (2010) concept of world-view shifting, which for her is the key to understanding the brain-washing and the influence of the manipulative public discourse. The novel by the Nobel prize winner for literature Kazuo Ishiguro The Buried Giant (2015) will be analyzed, parallelly with the book Fire and Fury: Inside the Trump White House (Wolff, 2018). Taking into account the concept of literariness as a potential of all language which may be present in different kinds of discourse as well as considering the vast exposure to the mass media messages, there was an intentional choice of a popular non- fictional text to be compared with the novel by Ishiguro.

The concrete analysis will apply CS tools that have been traditionally applied in CDA and which Fowler (2003, p. 40) has proposed as analytical tools for literature which he calls ideologically interesting', such as transitivity, participants, actions and processes, vocabulary, syntax, modality, generics, personal pronouns, speech acts. These linguistic indicators have been further developed by CS adding equating and contrasting, exemplifying and enumerating, assuming and implying.

Besides CS tools, in order to analyze more specifically Jeffries' notion of the world-view as an effect of deictic shifting, the concept of van Dijk (2010) about 'context' as subjective participant construct will be used in this study. In difference to the usual idea about contexts as objective properties of social, political, or cultural situations, van Dijk considers "contexts to be participant constructs or subjective definitions of interactional or communicative situations... contexts are mental models that people ongoingly construe of the situations and environments of their everyday lives" (16). According to van Dijk these mental models are shared and culturally based, thus allowing fast interpretations of communicative events (17). He characterizes these models with typical CDA and CS indicators such as 'participants', 'setting', 'events', 'actions', 'goals' in order to analyze their control of discourse production and comprehension. This concept of contexts is useful in understanding the interrelated dimension of socially shared attitudes, knowledge and ideologies with the subjective experience of contexts which as van Dijk says "are the center of my/our world... they are crucially ego-centric" (20).

As this paper is pointing out the effect of the text on the reader, the concept of 'speech act' is unavoidable. The conception of language as performative is associated to J.L Austin's speech act theory (1962), which distinguishes between the act of uttering (locutionary act), the performed act in saying something (illocutionary act) and in the performed act as a result of saying something (perlocutionary act).

\section{Results}

\subsection{Author's speech act in fiction and non-fiction}

Asked about the motivation for writing this novel, Ishiguro declared: "I was tempted to look at the actual contemporary events: The disintegration of Yugoslavia, the Rwanda genocide, France in the years after the Second World War ... But I didn't really, in the end, want to set it down in any of those particular settings. I didn't want to write a book that looked like a piece of reportage... As a novelist, I wanted to retreat to something a little bit more metaphorical" (NPR, 28.02.2015).

As this is a direct speech act of the author, his words generate the illocutionary force of his actual voice: the first person 'I' is labeled with individual properties of the vocation (novelist) and of the emotional state (tempted). This voice articulates concrete negative claims with negation implicatures of wanting to not set the story in 'particular settings' and of wanting to not write a 'piece of reportage'. Furthermore, the voice is targeting cognitive and moral goals of looking at concrete situations of 
disintegration of a state, genocide and war in others, and these goals will be achieved by 'retreating' from fact-reporting to aesthetic means (something - metaphorical). With his speech act he makes his world-view apparent and invites the reader to connect the deictic center of the fiction to the actual global events.

On the other hand, in the 'Author's note' Wolff says: "The reason to write this book could not be more obvious. With the inauguration of Donald Trump... the United States entered the eye of the most extraordinary political storm ...I set out to tell this story in as contemporaneous a fashion as possible, and to try to see life in the Trump White House through the eyes of the people closest to it. Many of the accounts of what has happened are in conflict with one another, many, in Trumpian fashion are baldly untrue. Those conflicts, and that looseness with the truth, if not with reality itself, is an elemental thread of the book (Fire and Fury, 2018, p.8-9).

Wolff's speech act is characterized by an impersonal voice who attributes the process of writing to 'the reason to write' and describes it as 'accounts of what has happened' intensifying the impartiality by using the modal negation 'could not be more obvious'. Although in impersonal mode, this voice makes generic statements and evaluations (political storm, contemporaneous fashion), it assigns objectivity to the speech act (I try to see life... through the eyes of the people) through multiple versions of reality (in conflict with one another) which reflect cognitive and moral conditions such as 'looseness with truth, if not with reality' leading towards the ultimate message which 'is thread of the book'.

\subsection{Reading as construction: the illocutionary act}

This is how The Buried Giant begins:

"You would have searched a long time for the sort of winding lane of tranquil meadow for which England later became celebrated. There were instead miles of desolate, uncultivated land; here and there rough-hewn paths over craggy hills or bleak moorland. Most of the roads left by the Romans would by then have become broken or overgrown, often fading into wilderness. Icy fogs hung over rivers and marshes, serving all too well the ogres that were then still native to this land" (Chapter one, para.1)

"In one such area on the edge of a vast bog, in the shadow of some jagged hills, lived an elderly couple, Axl and Beatrice. Perhaps these were not their exact or full names, but for ease, this is how we will refer to them." (Chapter one, para.3)

"You may wonder why Axl did not turn to his fellow villagers for assistance in recalling the past, but this was not as easy as you might suppose. For in this community the past was rarely discussed. I do not mean that it was taboo. I mean that it had somehow faded into a mist as dense as that which hung over the marshes. It simply did not occur to these villagers to think about the past -even the recent one." (Chapter one, para.12)

The text starts with first-person narration immediately addressing the second person, and this deictic shifting creates a space which can be filled by the reader as the addressee is non-apparent. Furthermore, while putting emphasis in the activity of narrating (this is how we will refer to them) the narrator includes the addressee in this activity. Besides being a property of postmodernist prose - going back at least to Cervantes, this direct and overt narratorial agency takes the function of tentativeness and unreliability, through markers such as the modality of possibility (perhaps) and back shifted preterits (would, might). It is interesting that the figural and existential coexist and they are equated and contrasted: "the past was rarely discussed not because it was taboo, but because it had faded into a dense mist". The novel not only refers to the act of narration, but likewise increases the awareness of the metaphoric nature of language: the lack of ability to remember is due to the mist, which relates to the conceptual metaphor of understanding and knowing as seeing, such as in expressions such as "make out", "something is clear", "a knowing person is bright" and so on. 
This is the beginning of Fire and Fury: Inside the Trump White House:

"The evening began at six-thirty, but Steve Bannon, suddenly among the world's most powerful men and now less and less mindful of time constraints, was late... Quite as dumbfounded by his old friend Donald Trump's victory as most everyone else, Ailes provided the gathering with something of a miniseminar on the randomness and absurdities of politics... accused of sexual harassment, (he) was cashiered from Fox News in a move engineered by the liberal sons of conservative eighty-five-year-old Rupert Murdoch... Then Trump, hardly three months later, accused of vastly more louche and abusive behavior, was elected president... Ailes enjoyed many things about Trump: his salesmanship, his showmanship, his gossip... his sixth sense for the public marketplace.... his shamelessness" (p.11-12).

The text suggests objectivity by direct representation of character's words, who similarly to Trump are specific social actors. The representational perspective is also denoted by concrete place, time and reason, and the process covers generalized abstraction over series of specific social events. As Nünning states (1999), the response of the reader depends on the general world knowledge, cultural codes, models of literary genres, intertextual frames, stereotyped models of character, norms established by the respective work itself. The text aims the ideological effect of constructed opposition: people "enjoy" demagogic content and disinformation (salesmanship, showmanship, gossip, shamelessness) and they act as willing participants of deception and at the same time they feel victims of it (dumbfounded by Trump's victory as most everyone else).

\subsection{The perlocutionary effect: what is the text doing?}

The Buried Giant has the historical setting in the medieval Britain, yet it reflects on everlasting conflicts of humankind raising the question whether peace may be achieved by disremembering the violence and crimes of the past. The following fragments from the Chapter six of the novel invoke a multiplicity of voices and viewpoints by means of clashing labels such as "good people", "civilized people", "savages", "merciful god", "useful god", "bribed god":

"They know the infants they circle in their arms will before long be bloodied toys kicked about these cobbles. They know because they've seen it already, from whence they fled. They've seen the enemy burn and cut, take turns to rape young girls even as they lie dying of their wounds." (Chapter six, para.79)

"I won't believe it sir. How is it possible to hate so deeply for deeds not yet done? The good people who once took shelter here would have kept alive hopes and surely watched all suffering, of friend and foe, with pity and horror." (Chapter six, para.80)

"Is your Christian god one to be bribed so easily with self-inflicted pain and a few prayers? Does he care so little for justice left undone?” (Chapter six, para.136)

"Our god is a god of mercy, shepherd, whom you, a pagan, may find hard to comprehend. It's no foolishness to seek forgiveness from such a god, however great the crime." (Chapter six, para.137)

"What use is a god with boundless mercy, sir? You mock me as a pagan, yet the gods of my ancestors pronounce clearly their ways and punish severely when we break their laws". (Chapter six, para.138)

The reader is exposed to contradicting beliefs about fundamental concepts such as "war" and "enemy", "God" and "mercy", "hatred", "forgiveness". The enemy is considered such, not because of his actual actions, but because of "deeds not yet done", and the hate is taken for granted. The vicious circle of hate is depicted for the reader, interwoven with the justification or the punishment of gods. This exploration of difference is undertaken in a dialogue between characters while walking, which is a conceptual metaphor of thinking, typical for expressions used in everyday conversations such as "reach a conclusion", "follow a story", "maze of ideas". The whole narrative is a journey undertaken by the 
couple in search for their memories, buried with the giant, which once alive again, awakens dreadful pasts.

On the other hand, in the following passage from non-fiction, the attribution of authorship to evaluations is given through abstract and generalized subjects:

"Here was, arguably, the central issue of the Trump presidency, informing every aspect of Trumpian policy and leadership: he didn't process information in any conventional sense- or, in a way, he didn't process it at all. Trump didn't read. He didn't really even skim. If it was print, it might as well not exist. Some believed that for all practical purposes he was no more than semiliterate. (There was some argument about this, because he could read headlines and articles about himself, or at least headlines on articles about himself, and the gossip squibs on the New York Post's Page Six.) Some thought him dyslexic; certainly, his comprehension was limited. Others concluded that he didn't read because he just didn't have to, and that in fact this was one of his key attributes as a populist. He was post-literate-total television." (123-4)

In the text there is indirect reporting and free indirect reporting of the speech and thoughts of generalized and quantified subjects (some, others, there was some argument) taking mental-state verbs (believed, thought, concluded) which trigger factual assumptions about mental cognition processes (process information, read, comprehend) of Trump. Taking into account the intensifiers (every aspect, certainly, in fact) and the social role of the participants of the events, the assumed meanings of qualifications such as "dyslexic", "semiliterate", "populist", are taken as given. Although the journalist claims to merely report the voices of the others, "the reporting of speech is never mere reproduction, but a representation, even in the case of direct speech or free indirect speech, because the writer can choose "what parts of the speech reported to include, in what order, and within what discoursal matrix"." (Hall, 2005, p.157)

\section{Discussion}

Comparing the direct statements by authors in both cases of fiction and non-fiction, the accomplishment of the perlocutionary power is enabled through social circumstances that attribute particular value to these acts. In the case of Ishiguro, he has won the Nobel prize for literature, and the Swedish Art academy when awarding him the prize has recognized the perlocutionary effect of his novels: "in novels of great emotional force, has uncovered the abyss beneath our illusory sense of connection with the world" (The Nobel prize, 2017). Whereas in the case of Wolff, Trump's lawyers tried to stop the publication of his book and a legal notice was sent to author and publisher with charges including libel, which is direct emphasizing the perlocutionary power of political discourse. The author of the fiction points out the intended perlocutionary effect relating it to the moral and aesthetic power of the text which he directly qualifies as non-factual, whereas the author of the non-fictional text creates the image of objectivity for the reader, which is ascribed to the multiple sources of information, one of the ultimate criteria of professional journalism. To refer to the concept of van Dijk about contexts, fiction decontextualizes readers' mental models by relating 'truth' to metaphorical language, whereas nonfiction invites readers to share the culturally based notion of 'truth' as objectivity which is guaranteed with documented voices thus allowing fast interpretation of the communicative events within the biography of Trump.

The start of the novel is self-reflection on narratorial agency, triggering the awareness of reading as construction and producing the effect of unreliability. Whereas the non-fictional text does the opposite, by assuming that the readers share the implicit value system with the narrator in order to achieve the ironical purpose of the text. The novel accords direct reference to the metaphorical language suspending 
the distinction between the literal and the figural, whereas the media narrator represents evaluations as objective states, assuming neutrality and relying on the generic attributes of the genre of the text. The novel invites the reliability judgment of the reader and the awareness of the act of narration, while on the other hand the mediatic discourse represents the judgmental opinion as objective description which should be taken for granted by the reader.

By being subjected to challenging and conflicting beliefs about essential social concepts, Ishiguro's novel produces the effect of 'dialogic' and 'hybrid' structures that Bakhtin (1981) considers as the actual state of all utterances, therefore for him the novel is an ideological polyphony. The diversity of ideological perspectives in the text produces deictic shifting for the reader due to the effect of different mental models offered about the same communicative situation. This deictic shifting points towards the awareness about the construction and the limited perspective of the personal point of view, and it animates the sense-making process and arouses the "passion of (for) meaning" (Brooks, 1992, p.48).

On the contrary, the text of the non-fiction aspires rhetorical certainty and assurance of the reader by focusing on parameters which determine the degree of faithfulness according to Semino \& Wynne (2002) such as: the importance of what is being reported, the status, social role, and personality of the speaker and of the reporter. When these parameters mismatch the given qualifications, irony is produced and it also indicated in grammar as the proper noun becomes a regular attributive modifier such as "Trumpian".

\section{Conclusions}

The first research question about the significance of stylistic analysis for promoting CLA is interconnected with Fairclough's concept of CLA as a necessary tool in education to increase consciousness on ways of using language. The results of the analysis of fragments from fiction and nonfiction demonstrate that the stylistic approach of reading can be of direct use to students and teachers, pointing out textual features in different levels of language and depicting their function towards effects of the text as a speech act. This strategy of interpretation helps the teacher to keep away from the morally prescriptive language and to minimize the role of the final source of knowledge and truth. In case of fiction, the narratorial unreliability is not simply labeled as a literary device, it rather becomes a dialogue about the detachment between language and reality that everyone faces, as eventually none of us have full access to the truth. Whereas in the case of non-fiction, a similar rhetorical effect is indicated by the use of the reverse means, by way of the image of objectivity ascribed to the multiple documented voices. Correspondingly, the linguistic approach allows students to reflect on the interpretative nature of the text and to become aware about the 'naturalization' (Jeffries, 2010, p.9) of readings to the extent that they become 'common sense', as in the case of non-fiction where the judgmental opinion is presented as objective description which should be taken for granted by the reader.

Regarding the second research question about the effect of deictic shifting and the change of worldview in fiction and non-fiction, the results of the analysis suggest that they are comparable in both genres nevertheless produced with different means and achieving different outcomes. Whereas perlocutionary effects such as persuasion and ideological influence in the journalistic discourse project certainty and assurance of subjective definitions by making the world-view change appear natural, on the other hand, the deictic shifting in fiction as an effect of defamiliarization and narratorial unreliability becomes a powerful tool of awareness for multiple world-views and for self-reflection. The reading process in fiction becomes a query about self-knowledge, about the way how readers construct, challenge and alter their understandings. 
As the study shows, the stylistic approach to texts can be a useful tool in education to develop the critical language awareness by decoding texts as speech acts and by analyzing the discourse production and comprehension, which as van Dijk states, helps to understand the interrelated dimension of socially shared attitudes, knowledge and ideologies with the subjective experience (2010, pp.17-18). Ultimately, this becomes a vital tool to understand the linguistic character of social, political and ideological processes.

\section{Ethics Committee Approval}

The author(s) confirm(s) that the study does not need ethics committee approval according to the research integrity rules in their country (Date of Confirmation: December 11, 2020).

\section{References}

Austin, J. L. (1962). How to do things with words: The William James Lectures, J.O. Urmson \& M. Sbisà (Eds.). Cambridge MA: Harvard University Press.

Bakhtin, M.M.(1981). The dialogic imagination, C. Emerson \& M. Holquist (Trans.). Austin: University of Texas Press.

Booth, W. C. (1983). The rhetoric of fiction. Chicago: The University of Chicago Press.

Brooks, P. (1992). Reading for the plot: Design and Intention in Narrative. Harvard University Press.

Clark, T. (2006). Interpretation: Hermeneutics. In P. Waugh (Ed.), Literary theory and criticism. An Oxford Guide (pp.59-70). Oxford University Press.

Cohn, D. (1999). The distinction of fiction. John Hopkins University Press.

Cohn, D. (2000). Discordant narration. Style, 34(2), 307-314.

Foucault, M. (1977). Discipline and punish. The birth of the prison, A. Sheridan (Trans.). NY: Vintage books. Retrieved on February 2nd, 2020 from: https://monoskop.org/images/4/43/Foucault_Michel_Discipline_and_Punish_The_Birth_of_the_Pr ison_1977_1995.pdf

Fairclough, N. (2001). Language and power (2nd ed.). London: Longman.

Fairclough, N. (2003). Analyzing discourse: Textual analysis for social research. London: Routledge.

Fairclough, N. (2010). Critical discourse analysis (2nd ed.). London: Longman.

Fowler, R. (2003). Language in the news: Discourse and ideology in press. London: Routledge.

Green P. (2001). Critical literacy revisited. In H. Fehring \&P. Green (Eds.), Critical Literacy, (pp.712). International Reading Association.

Ishiguro, K. (2015). The buried giant. NY: Alfred A. Knopf. Kindle, EPUB.

Ishiguro, K. The persistence -and impermanence -of memory in 'The buried giant'. In National Public Radio. Retrieved on January 15, 2020 from: https://www.npr.org/2015/02/28/389530345/thepersistence-and-impermanence-of-memory-in-the-buried-giant

Hall, G. (2005). Who said that? Who wrote that? Reporting, representation, and the linguistics of writing. In C. R. Caldas-Coulthard \& M. Toolan (Eds.), The Writer's Craft, the Culture's Technology (pp. 151-167). NY: Rodopi. 
Jeffries, L. (2010). Opposition in discourse. The construction of oppositional meanings. London: Continuum International Publishing Group.

Kempe, A. (2001). No single meaning: Empowering students to construct socially critical readings of the text. In H. Fehring \& P. Green (Eds.), Critical literacy (pp.40-57). International Reading Association.

Matz, J. (2004). The modern novel: A short introduction. Oxford. UK: Blackwell Publishing.

McIntyre, D. (2011). The place of stylistics in the English curriculum. In L. Jeffries \& D. McIntyre (Eds.), Teaching Stylistics (pp. 9-29). Palgrave Macmillan.

Nünning, A. (1997). But why will you say that I am mad: On the theory, history, and signals of unreliable narration in British fiction. AAA Arbeiten Aus Anglistik and Amerikanistik, 2(1), 83-105. JSTOR. Web. 09-05-2016.

Nünning, A. (1999). Reconceptualizing the theory and generic scope of unreliable narration. In J. Pier (Ed.), Recent Trends in Narratological Research (pp.63 -84). Tours University Press.

Olson, G. (2003). Reconsidering unreliability: Fallible and untrustworthy narrators. Ohio State University Press, 11(2), 93-109.

Phelan, J. (2005). Living to tell about it, a rhetoric and ethics of character narration. Ithaca and London: Cornell University Press.

Riggan, W. (1981). Picaros, madmen, naïfs, and clowns: The unreliable first-person narrator. The University of Oklahoma Press.

Semino, S. \& Wynne, M. (2002). Revisiting the notion of faithfulness in discourse presentation using a corpus approach. Language and Literature ,11(4), 484-509.

Simpson, P. (2004). Stylistics. NY: Routledge.

Sternberg, M. \& Yacobi, T. 2015. (Un)reliability in narrative discourse: A comprehensive overview. Poetics Today, 36(4), 329-483. Duke University Press.

The Nobel Prize in Literature 2017. NobelPrize.org. Retrieved on February 18, 2020 from: https://www.nobelprize.org/prizes/literature/2017/press-release/

Todorov, T. (1966). Les catégories du récit littéraire. Communications, 8, 125-51.

van Dijk, T. A (2010). Discourse and context: A sociocognitive approach (2nd ed.). Cambridge University Press.

Weber, J. J. (1996). The stylistic reader. University Centre Luxemburg.

Wolff, M. (2018). Fire and fury: Inside the Trump White House. London: Little Brown. 


\section{Eleştirel dil farkındalığı için bir araç olarak stil bilimi}

\section{$\ddot{O ̈ z}$}

Bu çalışma, söylemde aktarılan ideolojileri değerlendirmek için çok önemli olan eleştirel dil farkındalığının (CLA) geliştirilmesinde stilistik analizin rolünü tartışmaktadır. Eleştirel Stilistik yaklaşım, kurgu ve kurgusal olmayan anlatı stratejilerini karşılaştırmak için kullanılır. Yüzlerce doğrulama sitesi insanlara 'gerçek anlamı' 'sahte anlamdan' nasıl ayıracaklarını anlatırken kitle iletişim araçlarında hakikat konusuna muğlak yaklaşımları göz önünde bulunduran bu çalışma, anlatılara dilbilimsel yaklaşımın okuyuculara yardımcı olarak eleştirel düşünmeyi teşvik edebileceğini savunuyor. Çağdaş edebi stratejilerin ışığında, edebiyat, okuyucunun çoklu anlamlarla ilişkili olarak metne açılma olarak yorumlamayı gerçekleştiren tarafında artan bir öz-bilgi ve içgörü anlamında 'hakikat' modu olarak onaylanır. Anlatı stratejilerine yönelik üslup yaklaşımı, kuralcı ve dogmatik okumaların engellenmesi ve eleştirel okuryazarlık için teşvik olarak belirtilmiştir.

Anahtar Sözcükler: kritik dil bilinci; Ishiguro; Wolff; deictic yer değiştirme; Güvenilmez anlatıcı; Konuşma eylemi.

\section{AUTHOR BIODATA}

Lindita Tahiri works at University of Prishtina "Hasan Prishtina".

Nuran Muhaxheri works at University of Prishtina "Hasan Prishtina" 